\title{
PENGARUH ASAM HUMAT DAN PEMUPUKAN P TERHADAP POPULASI DAN KEANEKARAGAMAN MESOFAUNA TANAH PADA PERTANAMAN JAGUNG DI TANAH ULTISOL
}

\section{EFECT OF HUMIC ACID AND FERTILIZATION PHOSPHATE ON POPULATION AND DIVERSITY OF SOIL MESOFAUNA ON CORN PLANTING IN ULTISOL SOIL}

\author{
Agung Nugroho ${ }^{1}{ }^{*}$, Ainin Niswati ${ }^{2}$, Hery Novpriansyah ${ }^{2}$ dan M. A. Syamsul Arif ${ }^{2}$ \\ ${ }^{1}$ Jurusan Agroteknologi Fakultas Pertanian Universitas Lampung, Bandar Lampung, Indonesia \\ ${ }^{2}$ Jurusan Ilmu Tanah Fakultas Pertanian Universitas Lampung, Bandar Lampung, Indonesia \\ *Email: agungnu1997@gmail.com \\ * Corresponding Author, Diterima: 26 Feb. 2021, Direvisi: 2 Apr. 2021, Disetujui: 24 Mei 2021
}

\begin{abstract}
Ultisol is one type of soil that has a problem soil acidity, organic matter and macro nutrients is low and has a very low $P$ availability. Businesses that can be done to improve the quality Ultisol by implementing the use offertilizer $P$ with one ingredient soil (humic acid). The research aims to study the effect of humic acid applications, fertilization $P$, and the interaction between the population and the diversity of soil mesofauna. This study was conducted in December 2018 until April 2019 at the Experimental Station of Agricultural Technology Assessment Agency (BPTP) Natar, using a randomized block design arranged as factorial with two treatment factors. The first factor is the application of humic acid which is divided into 3 dose level without application of humic acid $\left(H_{0}\right), 15 \mathrm{~kg} \mathrm{ha}^{-1}$ humic acid $\left(H_{1}\right)$ And $30 \mathrm{~kg} \mathrm{ha}^{-1}$ humic acid $\left(H_{2}\right)$. The second factor is fertilizer $P$ were divided into 4 levels ie without TSP fertilizer dose $\left(P_{0}\right), T S P$ $100 \mathrm{~kg} \mathrm{ha}^{-1}\left(P_{1}\right)$, TSP $200 \mathrm{~kg} \mathrm{ha}^{-1}\left(P_{2}\right)$ And $300 \mathrm{~kg} \mathrm{ha}^{-1}$ TSP fertilizer(P $\left.P_{3}\right)$. Data was tested with Bartlett's test of homogeneity manifold and aditifitas data is tested by Tukey's test. The next test Least Significant Difference (LSD) at 5\% level. The relationship between C-organic soil, soil pH, soil moisture, soil temperature and soil mesofauna were tested with correlation. The results showed that the application of humic acid and fertilizer $P$ is able to affect the population and diversity mesofauna land, and there is interaction between the application of humic acid and $P$ fertilization on population anddiversity soil mesofauna. Only there is a correlation between soil pH and soil temperature with the population and diversity of soil mesofauna.
\end{abstract}

Keywords: Humic acid, fertilizer P, soil mesofauna, ultisol.

\begin{abstract}
ABSTRAK
Ultisol merupakan salah satu jenis tanah yang memiliki masalah kemasaman tanah, bahan organik dan nutrisi makro rendah dan memiliki ketersediaan P sangat rendah. Usaha yang dapat dilakukan untuk meningkatkan kualitas tanah ultisols yaitu dengan menerapkan penggunaan pupuk $\mathrm{P}$ dengan salah satu bahan pembenah tanah (asam humat). Penelitian bertujuan untuk mempelajari pengaruh aplikasi asam humat, pemupukan P, dan interaksi antara keduanya terhadap populasi dan keanekargaman mesofauna tanah. Penelitian ini dilaksanakan Desember
\end{abstract}


2018 sampai dengan April 2019 di Kebun Percobaan Badan Pengkajian Teknologi Pertanian (BPTP) Natar, menggunakan Rancangan Acak Kelompok yang disusun secara faktorial dengan dua faktor perlakuan. Faktor pertama yaitu aplikasi asam humat yang dibagi menjadi 3 taraf dosis yaitu tanpa aplikasi asam huma $\mathrm{t}(\mathrm{H} 0)$, asam humat $15 \mathrm{~kg} \mathrm{ha}^{-1}\left(\mathrm{H}_{1}\right)$ dan asam humat $30 \mathrm{~kg} \mathrm{ha}^{-1}\left(\mathrm{H}_{2}\right)$. Faktor kedua yaitu pemupukan $\mathrm{P}$ yang dibagi menjadi 4 taraf dosis yaitu tanpa pupuk TSP (P0), pupuk TSP $100 \mathrm{~kg} \mathrm{ha}^{-1}(\mathrm{P} 1)$, pupuk TSP $200 \mathrm{~kg} \mathrm{ha}^{-1}(\mathrm{P} 2)$ dan pupuk TSP $300 \mathrm{~kg} \mathrm{ha}^{-1}$ (P3). Data yang diperoleh diuji homogenitas ragamnya dengan uji Bartlett dan aditifitas data diuji dengan uji Tukey. Selanjutnya dilakukan uji Beda Nyata Terkecil (BNT) pada taraf 5\%. Hubungan antara C-organik tanah, $\mathrm{pH}$ tanah, kadar air tanah, dan suhu tanah dengan mesofauna tanah diuji dengan uji korelasi. Hasil penelitian menunjukkan bahwa aplikasi asam humat dan pemupukan $P$ mampu mempengaruhi populasi dan keanekargaman mesofauna tanah, serta terdapat interaksi antara aplikasi asam humat dan pemupukan P terhadap populasi dan keanekargaman mesofauna tanah. Hanya terdapat korelasi antara $\mathrm{pH}$ tanah dan suhu tanah dengan populasi dan keanekaragaman mesofauna tanah.

Kata kunci : Asam humat, mesofauna tanah, pemupukan P, ultisol.

\section{PENDAHULUAN}

Tanah Ultisol adalah tanah yang berwarna kuning kecoklatan hingga merah yang terbentuk dari bahan induk tufa masam, batu pasir atau sedimen kuarsa, dan tanah ultisol cenderung bersifat masam dengan unsur hara rendah. Memiliki pH rendah yaitu $(<5,0)$ dengan kejenuhan Al mencapai 42\%. Kondisi kesuburan tanah ultisol seperti itu menyebabkan tanaman yang tumbuh akan mengalami gangguan. Permasalahan tanah Ultisol yang lain adalah rendahnya kandungan bahan organik yaitu kurang dari 1,15\%, kandungan hara $\mathrm{N}$ dan $\mathrm{P}$ rendah, dan kapasitas tukar kation yang rendah (Alibasyah, 2016).

Chen danAvaid(1990)menyatakan bahwa salah satu cara untuk mengatasi permasalahan pada tanah Ultisol yaitu dengan penambahan bahan orgnaik. Bahan organik yang dapat digunakan untuk mengatasipermasalahan tanah Ultisol adalah asam humat. Pengaruh asam humat dalam mempengaruhi salah satunya pertumbuhan tanaman dapat secara langsung dan tidak langsung.

Pengaruh secara tidak langsung yaitu melalui perbaikan sifat-sifat tanah, sehingga serapan hara oleh tanaman meningkat, sehingga pertumbuhan tanaman juga meningkat. Pengaruh secara langsung adalah melalui perbaikan proses metabolisme dalam tanaman, seperti peningkatan respirasi akar, sintesis protein, dan asam nukleat.

Permasalahan tanah Ultisol yang cukup berpengaruh pada pertumbuhan tanaman yaitu sedikitnya kandungan P. Permasalahan lain disebabkan adanya reaksi antara unsur $\mathrm{P}$ dengan unsur-unsur logam di dalam tanah seperti Al dan Fe, sehingga nilai efisiensi pemupukan fosfor menjadi rendah. Pemupukan $\mathrm{P}$ merupakan alternatif yang efektif untuk meningkatkan unsur hara P di dalam tanah (Maulana dkk., 2014).

Asam humat dapat digunakan untuk meningkatkan kesuburan tanah. Asam humat merupakan suatu molekul kompleks yang terdiri atas kumpulan berbagai macam bahan organik yang berasal dari residu hasil dekomposisi tanaman dan hewan.Maka dari itu, dapat diartikan asam humat dapat digunakan sebagai bahan pembenah tanah. Selain akan 
memperbaiki sifat fisik dan kimia tanah, pemberian asam humat kedalam tanah kemungkinan akan memperbaiki juga sifat biologi tanah. Demikian juga pemberian pupuk $\mathrm{P}$ dengan dosis berbeda-beda akan mempengaruhi produksi tanaman yang kemungkinan juga akan mempengaruhi sifat kimia maupun sifat biologi tanah. Organisme yang memiki peranan penting dalam membantu proses penguraian bahan organik salah satunya adalah mesofauna. Peran aktifmesofauna tanah dalam menguraikan bahan organik yaitu dapat mempertahankan dan mengembalikan produktivitas tanah dengan didukung faktor lingkungan disekitarnya. Mesofauna merupakan salah satu organisme tanah yang dapat dijadikan bioindikator mengenai kualitas atau kesuburan tanah (Suwondo, 2002).

Organisme tanah saling berinteraksi dengan kebutuhannya akan bahan organik, karena bahan organik menyediakan energi untuk tumbuh. Sementara itu, kadar air tanah, suhu, $\mathrm{pH}$ tanah, atau C-organik mempengaruhi secara tidak langsung. Karena keempat variabel tersebut bergantung pada tingkat kesuburan tanah yang kemudian akan mempengruhi perkembangan organisme tanah (Husamah dkk., 2016).

\section{BAHAN DAN METODE}

\section{Desain Penelitian dan Analisis Data}

Penelitian dilakukan pada bulan Desember 2018 sampai dengan April2019 di Kebun Percobaan Badan Pengkajian Teknologi Pertanian (BPTP) Natar dan analisis tanah dilakukan di Laboratorium Ilmu Tanah Fakultas Pertanian Universitas Lampung. Penelitian dilakukan dengan menggunakan Rancangan Acak Kelompok yang disusun secara factorial dengan dua faktor perlakuan. Faktor pertama yaitu aplikasi asam humat yang dibagi menjadi 3 taraf dosis yaitu tanpa aplikasi asam humat, asam humat $15 \mathrm{~kg}$ ha-1 da asam humat $30 \mathrm{~kg}$ ha-1. Faktor kedua yaitu pemupukan $\mathrm{P}$ yang dibagi menjadi 4 taraf dosis yaitu tanpa pupuk TSP, pupuk TSP $100 \mathrm{~kg}$ ha-1, pupuk TSP $200 \mathrm{~kg}$ ha1 dan pupuk TSP $300 \mathrm{~kg}$ ha-1. Setiap perlakuan diulang sebanyak 3 kali sehingga diperoleh 36 satuan percobaan. Data yang diperoleh dilakukan uji homogenitas ragam dengan uji Bartlett dan aditifitas data diuji dengan uji Tukey. Jika asumsi terpenuhi maka akan dilakukan analisis ragam. Selanjutnya dilakukan uji Beda Nyata Terkecil(BNT) pada taraf 5\%.

\section{Seting Tanah dan Tanaman}

Tanah diolah sebanyak 2 kali dengan menggunakan traktor hingga tanah menjadi gembur. Lahan yang telah diolah kemudian dibagi menjadi 36 plot percobaan dengan ukuran masing-masing plot yaitu $3 \times 4 \mathrm{~m}^{2}$. Jarak antar plot adalah $50 \mathrm{~cm}$ dan jarak antar ulangan adalah 1 meter. Penanaman dilakukan dengan cara ditugal yang memiliki kedalaman $3 \mathrm{~cm}$. Jarak tanam yang digunakan adalah $25 \times 75 \mathrm{~cm}$ dan dalam setiap lubang diberi 2 butir benih jagung.

\section{Pengamatan Mesofauna Tanah}

Pengambilan dilakukan sebanyak 3 kali yaitu pada setelah olah tanah, pada fase vegetatif maksmum dan sebelum panen. Sampel tanah diambil menggunakan ring sampel dengan ukuran tinggi $5 \mathrm{~cm}$ dan jari-jari 2,75 cm sebanyak 5 titik dalam satu plot. Pengekstrakan mesofauna tanah menggunakan Barlese Tullgren yang telah dilengkapi saringan dengan diameter $2 \mathrm{~mm}$ dan lampu 25 watt selama 2 hari (48 jam). Setelah disinari selama 48 jam, mesofauna tanah akan tutun dan masuk 
ke dala botol film yang berisi alkoho 70\%. Mesofauna yang berada dalam botol film kemudian dipindahkan ke cawan petri dan diamati menggunakan mikroskop dengan perbesaran 40-200 kali. Data mesofauna yang terhitung dikonversi ke dalam populasi mesofauna tanah dengan rumus:

$$
\text { Populasi }=\frac{\text { Jumlah mesofauna tanah }(\text { ekor })}{\text { Volume ring sampel }\left(\mathrm{dm}^{-3}\right)}
$$

Untuk menghitung kenekaragaman mesofauna tanah dihitung dengan menggunakan rumus ShannonWhever (Odum, 1983).

$$
H^{\prime}=-\sum[(n i / N) \operatorname{In}(n i / N)]
$$

\section{Keterangan:}

$\mathrm{H}^{\prime}=$ Indeks keanekaragaman jenis Shannon-Wheaver

$\mathrm{ni}=$ Jumlah individu jenis ke-i

$\mathrm{N}=$ Total individu yang ditemukan

Variabel pendukung yaitu kadar air tanah, Corganik, Suhu tanah, dan $\mathrm{pH}$ tanah.diamati secara bersamaan dengan melakukan pengukuran mesofauna tanah pada saat fase vegetatifawal, vegetatif maksimum dan sebelum panen.

\section{HASIL DAN PEMBAHASAN}

\section{Populasi MesofaunaTanah}

Berdasarkan ringkasan analisis ragam (Tabel2) menunjukkan bahwa perlakuan asam humat $(\mathrm{H})$ dan pemupukan $\mathrm{P}(\mathrm{P})$ berpengaruh nyata pada semua waktu pengamatan serta interaksi antara asam humat dengan pemupukan $\mathrm{P}(\mathrm{H} \times \mathrm{P})$ berpengaruh nyata pada vegetatif maksimum dan sebelum panen. Sejalan dengan hasil penelitian Murray dkk., (2006), bahwa aplikasi pupuk anorganik dan organik sejauh ini berperan aktif dalam peningkatan populasi mesofauna tanah. Penambahan bahan organik yang diberikan setelah dilakukan olah tanah berguna untuk suplai energi bagi mesofauna tanah selama pertumbuhan tanaman jagung.

Berdasarkan hasil uji BNT terhadap populasi mesofauna tanah pada vegetatif awal (Tabel 3) menunjukkan bahwa perlakuan yang paling baik terhadap populasi mesofauna tanah adalah aplikasi asam humat $15 \mathrm{~kg} \mathrm{ha}^{-1}$ dan $30 \mathrm{~kg} \mathrm{ha}^{-1}$. Hasil pengamatan pengaruh aplikasi pemupukan $\mathrm{P}$ terhadap populasi mesofauna tanah pada vegetatifawal (Tabel4) menunjukkan bahwa perlakuan yang paling baik

Tabel 1. Kriteri Indeks Keanekragaman Shannon-Wheaver (Odum, 1983).

\begin{tabular}{cc}
\hline Indeks Keanekragaman & Kriteria Keanekragaman \\
\hline $\mathrm{H}=2$ & Rendah \\
$2<\mathrm{H}=3$ & Sedang \\
$\mathrm{H}>3$ & Tinggi \\
\hline
\end{tabular}

Tabel2. Ringkasan analisis ragam pengaruh aplikasi asam humat dan pemupukan P terhadap populasi mesofauna tanah pada pengamatan 14 HST, 50 HST dan 90 HST pada pertanaman jagung (Zea mays L.).

\begin{tabular}{cccc}
\hline Sumber Keragaman & F hitung dan signifikansi \\
\hline H & $10,03^{*}$ & $3,74^{*}$ & $12,51^{*}$ \\
P & $3,69^{*}$ & $4,35^{*}$ & $8,75^{*}$ \\
H x P & $0,46^{\text {th }}$ & $4,31^{*}$ & $3,90^{*}$ \\
\hline
\end{tabular}

Keterangan: $\mathrm{H}=$ asam humat; $\mathrm{P}=$ pemupukan $\mathrm{P} ; \mathrm{HxP}=$ interaksi asam humat dan pupukP; $\mathrm{tn}=$ tidak nyata pada taraf $5 \%$. 
Tabel 3. Pengaruh asam humat terhadap popilasi mesofauna tanah pada vegetatif awal (14 HST) di pertanaman jagung(Zea mays L.).

\begin{tabular}{lc}
\hline \multicolumn{1}{c}{ Perlakuan } & $\left(\mathrm{ekor} \mathrm{dm}^{-3}\right)$ \\
\hline Tanpa asam humat & $11 \mathrm{a}$ \\
Asam humat $\left(15 \mathrm{~kg} \mathrm{ha}^{-1}\right)$ & $19 \mathrm{~b}$ \\
Asam humat $\left(30 \mathrm{~kg} \mathrm{ha}^{-1}\right)$ & $23 \mathrm{~b}$ \\
\hline Nilai BNT $5 \%$ & 6 \\
\hline
\end{tabular}

Tabel 4. Pengaruh pemupukan P terhadap populasi mesofauna tanah pada vegetatifawal (14 HST) di pertanaman jagung (Zea mays L.).

\begin{tabular}{lc}
\hline \multicolumn{1}{c}{ Perlakuan } & $\left(\mathrm{ekor} \mathrm{dm}^{-3}\right)$ \\
\hline Tanpa asam humat & $11 \mathrm{a}$ \\
Asam humat $\left(15 \mathrm{~kg} \mathrm{ha}^{-1}\right)$ & $19 \mathrm{~b}$ \\
Asam humat $\left(30 \mathrm{~kg} \mathrm{ha}^{-1}\right)$ & $23 \mathrm{~b}$ \\
\hline Nilai BNT 5\% & 6 \\
\hline
\end{tabular}

Tabel 5. Pengaruh aplikasi asama humat dan pemupukan $\mathrm{P}$ terhadap populasi mesofauna tanahpada vegetatif maksimum (50 HST) di pertanaman jagung Jagung (Zea maysL.).

\begin{tabular}{lcccc}
\hline \multirow{2}{*}{ Aplikasi Asam Humat } & \multicolumn{4}{c}{ Populasi Mesofuna Tanah } \\
\cline { 2 - 5 } & 0 & 100 & 200 \\
\cline { 2 - 5 } & $22 \mathrm{a}$ & $65 \mathrm{~b}$ & $6 .$. & 300 \\
\hline \multirow{2}{*}{ Tanpa asam humat } & $\mathrm{A}$ & $\mathrm{A}$ & $\mathrm{A}$ & $56 \mathrm{~b}$ \\
& $62 \mathrm{a}$ & $56 \mathrm{a}$ & $51 \mathrm{a}$ & $\mathrm{A}$ \\
Asam humat $\left(15 \mathrm{~kg} \mathrm{ha}^{-1}\right)$ & $\mathrm{B}$ & $\mathrm{A}$ & $\mathrm{A}$ & $62 \mathrm{a}$ \\
& $56 \mathrm{a}$ & $56 \mathrm{a}$ & $67 \mathrm{ab}$ & $\mathrm{AB}$ \\
Asam humat $\left(30 \mathrm{~kg} \mathrm{ha}^{-1}\right)$ & $\mathrm{B}$ & $\mathrm{A}$ & $\mathrm{A}$ & $79 \mathrm{~b}$ \\
\hline Nilai BNT 5\% & 17 & & $\mathrm{~B}$ \\
\hline
\end{tabular}

Keterangan: data yang diikuti huruf kecil dibaca secara horizontal dan huruf kapital di bawah data dibaca secara vertikal

terhadap populasi mesofauna tanah adalah pemberian pupuk TSP $300 \mathrm{~kg} \mathrm{ha}^{-1}$, dikarenakan pemberian pupuk TSP $100 \mathrm{~kg} \mathrm{ha}^{-1}$ dan $200 \mathrm{~kg} \mathrm{ha}^{-1}$ tidak menunjukkan perbedaan dengan tanpa pupuk TSP. Sejalan dengan hasil penelitian Andanda dkk. (2017), bahwa hasil pengamatan pada perlakuan tanpa bahan organik dan anorganik menunjukkan jumlah populasi mesofauna tanah terendah. Hasil uji BNT pada pengamtan vegetatif maksimum(Tabel 5), menunjukkan kombinasi yang paling baik pada perlakuan tanpa asam humat dengan pemberian pupuk TSP $100 \mathrm{~kg} \mathrm{ha}^{-1}, 200 \mathrm{~kg} \mathrm{ha}^{-1}$ dan $300 \mathrm{~kg} \mathrm{ha}^{-1}$, tetapi pada aplikasi asam humat $15 \mathrm{~kg}$ ha $^{-1}$ dengan dosis pemupukan P tidak berbeda dengan tanpa pupuk TSP. Sedangkan kombinasi yang paling baik terhadap populasi mesofauna tanah pada aplikasi asam humat $30 \mathrm{kgha}^{-1}$ adalah dengan pemberian pupuk TSP $300 \mathrm{~kg} \mathrm{ha}^{-1}$. Hal tersebut dapat terjadi karena pemberian pupuk TSP $100 \mathrm{~kg} \mathrm{ha}^{-1}$ dan pupuk TSP $200 \mathrm{~kg} \mathrm{ha}^{-1}$ tidak berbeda dibandingkan dengan tanpa pupuk TSP. 
Pada perlakuan tanpa pupuk TSP kombinasi yang paling baik terhadap populasi mesofauna tanah dengan dosis asam humat $15 \mathrm{~kg} \mathrm{ha}^{-1}$ dan asam humat $30 \mathrm{~kg} \mathrm{ha}^{-1}$, tetapi pada pemberian pupuk TSP $100 \mathrm{~kg}$ $\mathrm{ha}^{-1}$ dan $200 \mathrm{~kg} \mathrm{ha}^{-1}$ tidak berbeda dengan tanpa pupuk TSP. Sedangkan pada pemberian pupuk TSP $300 \mathrm{~kg}$ $\mathrm{ha}^{-1}$ kombinasi yang paling baik terhadap populasi mesofauna tanah dengan dosis asam humat $30 \mathrm{~kg} \mathrm{ha}^{-1}$. Hal tersebut dikarenakan aplikasi dosis asam humat $15 \mathrm{kgha}^{-1}$ tidak berbeda dengan tanpa aplikasi asam humat.

Hasil uji BNT pada pengamatan sebelum panen (Tabel 6), menunjukkan bahwa kombinasi yang paling baik terhadap populasi mesofauna tanah pada perlakuan tanpa asam humat adalah dengan pemberian pupuk TSP $100 \mathrm{~kg} \mathrm{ha}^{-1}, 200 \mathrm{~kg} \mathrm{ha}^{-1}$ dan $300 \mathrm{~kg} \mathrm{ha}^{-1}$.
Akan tetapi pada aplikasi asam humat $15 \mathrm{~kg} \mathrm{ha}^{-1} \mathrm{dan}$ asam humat $30 \mathrm{~kg} \mathrm{ha}^{-1}$ dengan dosis pemupukan $\mathrm{P}$ tidak berbeda dengan tanpa pupuk TSP. Pada perlakuan tanpa pupuk TSP kombinasi yang paling baik terhadap populasi mesofauna tanah adalah dengan dosis asam humat $15 \mathrm{~kg} \mathrm{ha}^{-1}$ dan asam humat $30 \mathrm{~kg}$ $\mathrm{ha}^{-1}$, tetapi pada pemberian pupuk TSP $100 \mathrm{~kg} \mathrm{ha}^{-1}$ dan $300 \mathrm{~kg} \mathrm{ha}^{-1}$ tidak berbeda dengan tanpa pupuk TSP. Sedangkan pada pemberian pupuk TSP $200 \mathrm{~kg}$ $\mathrm{ha}^{-1}$ kombinasi yang paling baik terhadap populasi mesofauna tanah adalah dengan dosis asam humat 15 $\mathrm{kg} \mathrm{ha}^{-1}$ dan asam humat $30 \mathrm{~kg} \mathrm{ha}^{-1}$.

\section{Indeks Keanekaragaman Mesofauna Tanah}

Ordo dan indeks keanekaragaman mesofauna tanah (Tabel 7) pada pengamatan ini jenis mesofauna

Tabel 6. Pengaruh aplikasi asama humat dan pemupukan P terhadap populasi mesofauna tanah pada sebelum panen (90 HST) di pertanaman jagung (Zea mays L.)

\begin{tabular}{lcccc}
\hline \multirow{2}{*}{ Aplikasi Asam Humat } & \multicolumn{4}{c}{ Populasi Mesofuna Tanah } \\
\cline { 2 - 5 } & 0 & 100 & 200 & 300 \\
\cline { 2 - 5 } & & \multicolumn{4}{c}{ P.... (ekor dm $\left.\mathrm{dm}^{-3}\right) \ldots \ldots$} \\
Tanpa asam humat & $79 \mathrm{a}$ & $112 \mathrm{~b}$ & $109 \mathrm{~b}$ & $115 \mathrm{~b}$ \\
& $\mathrm{~A}$ & $\mathrm{~A}$ & $\mathrm{~A}$ & $\mathrm{~A}$ \\
Asam humat $\left(15 \mathrm{~kg} \mathrm{ha}^{-1}\right)$ & $106 \mathrm{a}$ & $107 \mathrm{a}$ & $112 \mathrm{a}$ & $112 \mathrm{a}$ \\
& $\mathrm{B}$ & $\mathrm{A}$ & $\mathrm{B}$ & $\mathrm{A}$ \\
Asam humat $\left(30 \mathrm{~kg} \mathrm{ha}^{-1}\right)$ & $115 \mathrm{a}$ & $115 \mathrm{a}$ & $123 \mathrm{a}$ & $124 \mathrm{a}$ \\
\hline Nilai BNT 5\% & $\mathrm{B}$ & $\mathrm{A}$ & $\mathrm{B}$ & $\mathrm{A}$ \\
\hline
\end{tabular}

Keterangan: data yang diikuti huruf kecil dibaca secara horizontal dan huruf kapital di bawah data dibaca secara vertikal

Tabel 7. Ringkasan Analisis Ragam Pengaruh Aplikasi Asam Humat dan Pemupukan P terhadap Indeks Keanekaragaman Tanah pada Pengamatan 14 HST, 50 HST dan 90 HST di Pertanaman Jagung (Zea mays L.).

\begin{tabular}{cccc}
\hline Sumber Keragaman & F hitung dan signifikansi \\
\hline H & $7,95^{\text {tn }}$ & $20,05^{*}$ & $0,34^{\text {tn }}$ \\
P & $0,46^{\text {th }}$ & $17,44^{*}$ & $0,99^{\text {tn }}$ \\
H x P & $2,99^{\text {tn }}$ & $10,23^{*}$ & $0,78^{\text {tn }}$ \\
\hline
\end{tabular}

Keterangan: $\mathrm{tn}=$ tidak berbeda nyata pada taraf $5 \% ; *=$ berbeda nyata pada taraf $5 \% ; \mathrm{H}=$ asam humat; $\mathrm{P}=$ pemupukan $\mathrm{P} ;$ dan $\mathrm{Hx} \mathrm{P}=$ interaksi asam humat dan pemupukan $\mathrm{P}$. 
yang diperoleh hanya 6 jenis yaitu, Acarina Hymenoptera, Diptera, Diplura, Collembola dan lain-lain. Sementara itu nilai indeks keanekaragaman yang diperoleh semuanya masih kurang dari 2 dan menurut Shannon-Wiener nilai indeks tersebut masuk dalam kategori rendah. Hal ini diduga karena pada penelitian ini jenis mesofauna yang diperoleh hanya 6 jenis saja dan jumlah populasi mesofauna di setiapjenis nya sangat berbeda, sehingga keanekaragamannya kurang bervariasi. Menurut Suwondo (2002) apabila laju koefisien keanekaragaman kurang dari 1 maka laju dekomposisinya rendah, sehingga dari hasil penelitian ini penambahan asam humat dan pemupukan $P$ tidak berpengaruh terhadap keanekaragaman mesofaunatanah.

Faktor lainnya yang memungkinkan nilai indeks keanekaragaman rendah adalah berkaitan dengan faktor kesuburan tanah seperti $\mathrm{pH}, \mathrm{C}$-organik, kadar air dan suhu tanah yang rendah. Hasil dari uji korelasi (Tabel 10) hanya pada suhu tanah 50 HST dan 90 HST yang menunjukkan adanya korelasi dengan indeks keanekaragaman mesofauna tanah dan korelasi terjadi pada suhu dan $\mathrm{pH}$ tanah dengan populasi mesofauna tanah masing-masing pada 90 HST dan 50 HST.
Mesofauna tanah merupakan organisme dalam tanah yang memiliki peranan penting dalam dekomposisi bahan organik tanah.Mesofauna termasuk salah satu hewan heterotof.Hewan heterotof merupakan hewan yang memanfaatkan bahan organik sebagai energinya.Energi yang diperoleh dari bahan organik digunakan untuk aktivitas dan perkembangan mesofauna sehingga jumlah mesofauna selama pertanaman jagung terus meningkat.Meningkatnya suatu populasi tidak diikuti dengan meningkatnya suatu indeks kenekaragaman mesofauna tanah.Hal ini dikarenkan pemberian bahan organik diberikan pada awal sebelum tanam dan pemupukan P setelah tanam sehingga berpengaruh terhadap peningkatan populasi, tetapi tidak berpengaruh terhadap indeks keanekaragaman mesofauna tanah.

Hasil uji BNT pengaruh interaksi aplikasi asam humat dengan pemupukan $\mathrm{P}$ terhadap indeks keanekaragaman mesofauna tanah pada vegetatif maksimum dapat dilihat pada (Tabel 9). Pada perlakuan tanpa asam humat kombinasi yang paling baik terhadap indeks keanekaragaman mesofauna tanah adalah dengan pemberian pupuk TSP $100 \mathrm{~kg} \mathrm{ha}^{-1}, 200$

Tabel 9. Pengaruh aplikasi asam humat dan pemupukan $P$ terhadap indeks keanekaragaman mesofauna tanah pada vegetatif maksimum (50 HST) di pertanaman jagung.

\begin{tabular}{lcccc}
\hline \multirow{2}{*}{ Aplikasi Asam Humat } & \multicolumn{4}{c}{ Indeks Keanekaragaman Mesofauna Tanah } \\
\cline { 2 - 5 } & \multicolumn{4}{c}{ Pupuk TSP $\left(\mathrm{kg} \mathrm{ha}^{-1}\right)$} \\
\cline { 2 - 5 } Tanpa asam humat & $1,0 \mathrm{a}$ & 100 & 200 & 300 \\
& $\mathrm{~A}$ & $\mathrm{~A}$ & $1,5 \mathrm{~b}$ & $1,6 \mathrm{~b}$ \\
\multirow{2}{*}{ Asam humat $\left(15 \mathrm{~kg} \mathrm{ha}^{-1}\right)$} & $1,5 \mathrm{a}$ & $1,6 \mathrm{a}$ & $\mathrm{A}$ & $\mathrm{A}$ \\
\multirow{2}{*}{ Asam humat $\left(30 \mathrm{~kg} \mathrm{ha}^{-1}\right)$} & $\mathrm{B}$ & $\mathrm{A}$ & $1,5 \mathrm{a}$ & $1,6 \mathrm{a}$ \\
& $1,6 \mathrm{a}$ & $1,6 \mathrm{a}$ & $1,5 \mathrm{a}$ & $\mathrm{A}$ \\
Nilai BNT 5\% & $\mathrm{B}$ & $\mathrm{A}$ & $\mathrm{A}$ & $\mathrm{A}$ \\
\hline
\end{tabular}

Keterangan: data yang diikuti huruf kecil dibaca secara horizontal dan huruf kapital di bawah data dibaca secara vertikal 
Tabel 10. Ringkasan uji korelasi beberpa sifat tanah dengan populasi dan keanekaragaman mesofauna tanah.

\begin{tabular}{lcccccc}
\hline \multirow{3}{*}{ Variabel } & \multicolumn{5}{c}{ Koefisien Korelasi (r) } \\
\cline { 2 - 6 } & \multicolumn{3}{c}{ Populasi Mesofauna } & \multicolumn{3}{c}{ Indeks Keanekaragaman } \\
\cline { 2 - 6 } & 14 HST & 50 HST & 90 HST & 14 HST & 50 HST & 90 HST \\
\hline Kadar air tanah & $0,06^{\text {tn }}$ & $0,15^{\text {tn }}$ & $0,23^{\text {tn }}$ & $0,30^{\text {tn }}$ & $0,04^{\text {tn }}$ & $0,13^{\text {tn }}$ \\
Suhu tanah & $0,26^{\text {th }}$ & $0,10^{\text {tn }}$ & $0,44^{*}$ & $0,31^{\text {tn }}$ & $0,43^{*}$ & $0,51^{*}$ \\
pH tanah & $0,11^{\text {tn }}$ & $0,61^{*}$ & $0,20^{\text {tn }}$ & $0,10^{\text {tn }}$ & $0,40^{\text {tn }}$ & $0,04^{\text {tn }}$ \\
C-organik & $0,00^{\text {tn }}$ & $0,16^{\text {tn }}$ & $0,25^{\text {tn }}$ & $0,23^{\text {tn }}$ & $0,33^{\text {tn }}$ & $0,01^{\text {tn }}$ \\
\hline
\end{tabular}

Keterangan : tn $=$ tidak nyata pada taraf $5 \%$ dan * adalah nyata pada taraf $5 \%$.

$\mathrm{kg} \mathrm{ha}^{-1}$ dan $300 \mathrm{~kg} \mathrm{ha}^{-1}$, tetapi pada perlakuanasam humat $15 \mathrm{~kg} \mathrm{ha}^{-1}$ dan asam humat $30 \mathrm{~kg} \mathrm{ha}^{-1}$ dengan dosis pemupukan $\mathrm{P}$ tidak berbeda dengan tanpa asam humat. Demikian juga pada perlakuan tanpa pupuk TSPkombinasi yang paling baik terhadap indeks keanekaragaman mesofauna tanah adalah dengan dosis asam humat $15 \mathrm{~kg} \mathrm{ha}^{-1}$ dan $30 \mathrm{~kg} \mathrm{ha}^{-1}$, tetapi pada perlakuan pupuk TSP dengan dosis asam humattidak berbeda dengan tanpa pupuk TSP.

Faktor lain yang dapat mempengaruhi populasi dan keanekaragaman mesofauna tanah akan tetapi tidak berkorelasi diduga karena kondisi lingkungan yang cenderung memiliki suhu udara yang cukup panas. Selain itu, pada saat pengambilan sampel dilakukan pada pagi hari hingga siang hari dengan sinar matahari yang sangat terik karena bertepatan dengan musim kemarau.Faktor-faktor tersebut yang diduga mempengaruhi tidak adanya korelasi antara sifat-sifat tanah dengan populasi dan keanekaragaman mesofauna tanah.Lavelle (1997) menjelaskan bahwa keanekaragaman dan kepadatan populasi fauna tanah dipengaruhi oleh organisme tanah lainnya. Hal ini disebabkan semua organisme yang ada di dalam tanah akan saling berinteraksi satu sama lain. Interaksi yang mungkin terjadi yaitu, interaksi mutualisme dimana interaksi tersebut saling menguntungkan untuk masingmasing organisme serta adanya interaksi saling memangsa sehingga membentuk suatu rantai makanan.

\section{KESIMPULAN}

Berdasarkan hasil penelitian yang telah dilakukan dapat diambil kesimpulan bahwa aplikasi asam humat dan Pemupukan P mampu meningkatkan populasi dan keanekaragaman mesofauna tanah pada pertanaman jagung di tanah ultisol. Interaksi aplikasi asam humat dengan pemupukan $\mathrm{P}$ mampu meningkatkan populasi mesofauna tanah pada pertanaman jagung di tanah ultisol, akan tetapi tidak dapat meningkatkan keanekaragamannya. Hanya terdapat korelasi positif antara $\mathrm{pH}$ tanah dan suhu tanah dengan meningkatnya populasi dan keanekaragaman mesofauna tanah.

\section{DAFTAR PUSTAKA}

Alibasyah,A. R. 2016. Perubahan beberapa sifat fisika dan kimia Ultisol akibat pemberian pupuk kompos dan kapur dolomit pada lahan berteras.J.Floratek. 11(1): 75-87.

Borror, D. J., C. A. Tripelhorn dan N. F. Jhonson. 1996. Introduction to The Study of Insect, 
7th Edition. Halt Rine hart and Winstone. Ohio State University Columbus.

Chen Y, dan T. Aviad, 1990. Effect of Humic Substances on Plant Growth.In Humic Substances in Soil and Crop Sciences :Selected Readings. Eds. P Mac Carthy, CE Clapp, RL Malcolm and P.R. Bloom hal 161 168.American Society of Agronomy, Madison.

Husamah, Rohman, F., dan Sutomo, H. 2016. Pengaruh c-organik dan kadar air terhadap jumlah jenis dan jumlah individu collembola sepanjang daerah aliran sungai Brantas Kota Batu. Simposium.Universitas Muhamadyah Malang. Malang. hlm 392-410.

Murray, P. J., R. Cook, . F. Currei, L. A. Dawson, A. C. Gange, dan S. J. Grayston. 2006. Treonis Interctions Between Fertilizzer Addition Plants and the Soil Enviroment: Imlication for Soil Faunal Structure and Diversity. Apl. Soil Ecol. 33: 199-207.

Odum, E. P. 1983. Basic Ecology.Saunders College Publishing.New York. Pp 144.
Prasetyo, B. H. dan Suriadikarta, D. A. 2006. Karakteristik, potensi dan teknologi pengelolaan tanah ultisol untuk pengembangan pertanian lahan kering di Indonesia. J.Litbang Pertanian. 25(2): 39-47

Sari, M. N., Sudarsono dan Darmawan. 2017. Pengaruh bahan organik terhadapketersediaan fosfor pada tanah-tanah kaya Al dn Fe. Buletin Tanah dan Lahan. 1(1): 65-71.

Sarno dan Fitria, E. 2012.Pengaruh aplikasi asam humat dan pupuk $\mathrm{N}$ terhadap pertumbuhan dan serapan $\mathrm{N}$ pada tanaman bayam (Amaranthus spp.).Prosiding SNSMAIP III.288-293.

Suharjono, Y. R. 1997. Serangga Serasah, Keanekaragaman Takson Dan Peranannya Di Kebur Raya Bogor. Biota. 3: 16-24.

Trisilawati, O., Seswita D. Dan M. Syakir. 2017. Serapan Hara N, P, dan K pada Tujuh Nomor Harapan Serai Dapur pada Tanah Lalosol. J. Litrri. 23(2):105-111. 